\title{
Desemparedando a Educação Infantil: um processo formativo no estágio curricular
}

\section{Knocking down walls in early childhood education: a formative process in the curricular internship}

\section{Derribando muros de la educación infantil: un proceso formativo en la pasantía curricular}

\author{
Bibiana da Cunha Tubino' \\ https://orcid.org/0000-0003-0310-99IX \\ Simone Santos de Albuquerque ${ }^{2}$ \\ https://orcid.org/0000-0002-I I I -464X
}

\begin{abstract}
Resumo: A formação dos acadêmicos do Curso de Pedagogia engloba um grande desafio teórico-prático, o qual abrange o olhar sensível do professor em relação às crianças, o compromisso com os pressupostos teóricos que fundamentam a prática pedagógica e os registros e reflexões que emergem no cotidiano da escola. $O$ presente artigo apresenta relatos referentes a esse desafio e análises de um estágio docente realizado em creche conveniada, localizada na área central do município de Porto Alegre, com II crianças da turma de berçário, na faixa etária de I a 2 anos. A partir do conceito de desemparedamento nas experiências vivenciadas durante o estágio, são problematizadas as potencialidades e as dificuldades durante essa etapa de formação.
\end{abstract}

Palavras-chave: Educação Infantil. Estágio Docente. Desemparedamento. Espaço.

Abstract: The education of Pedagogy undergraduate students encompasses a major theoretical-practical challenge, which includes the sensitive view of the teacher towards children, the commitment to theoretical assumptions that underlie the practice and the records and reflections that emerges at the school's daily life. This article presents reports referring to this challenge and analyzes a teaching internship, held in an accredited daycare center, located in the central area of the city of Porto Alegre, with II children in the nursery class, aged I to 2 years. Based on the concept of knocking down walls in internship experiences, the potential and difficulties during this training stage are problematized.

Keywords: Early Childhood Education. Teaching Internship. Knocking Down Walls. Space.

\footnotetext{
' Graduada em Pedagogia pela Universidade Federal do Rio Grande do Sul. Professora na rede privada de ensino de Porto Alegre. E-mail: bibianac.t133@gmail.com

${ }^{2}$ Doutora em Educação pela Universidade Federal do Rio Grande do Sul. Professora Associada da Faculdade de Educação da UFRGS. E-mail: sialbuq@gmail.com
}

Olhar de professor, Ponta Grossa, v. 24, p. I-19, e-15955.006, 2021.

Disponível em <https://revistas2.uepg.br/index.php/olhardeprofessor> 
Resumen: La formación de los estudiantes de la Carrera de Pedagogía implica un gran desafío teórico-práctico, que incluye la mirada sensible del maestro en relación con los niños, el compromiso con los fundamentos teóricos que basan la práctica pedagógica y los registros y reflexiones que surgen en el día a día de la escuela. Este artículo presenta relatos que se refieren a este desafío y análisis de una pasantía docente, realizada en una guardería acreditada, ubicada en el área central de la ciudad de Porto Alegre, con I I niños, de I a 2 años, de un grupo de la guardería. Basándose en el concepto de derribar los muros en las experiencias de la pasantía, se discuten las potencialidades y las dificultades durante esta etapa de formación.

Palabras-clave: Educación Infantil. Pasantía Docente. Derribando muros. Espacio.

\section{Introdução}

O curso de Pedagogia da Universidade Federal do Rio Grande do Sul prevê, no seu projeto pedagógico, que ao final do oitavo semestre do curso os acadêmicos façam sua escolha sobre qual será a etapa da educação básica na qual irão realizar o seu estágio curricular que compõe o total de 360 horas de prática em escola. Para as alunas que fazem a escolha pela Educação Infantil, esta experiência é feita de forma individual, numa escola pública e/ou conveniada, credenciada pelo Conselho Municipal de Educação, durante 15 semanas letivas. Durante o estágio curricular, as acadêmicas são acompanhadas por um(a) professor(a) orientador(a) ${ }^{3}$ da área da Educação Infantil, que orienta o processo de planejamento e faz o acompanhamento da proposta desenvolvida na escola. As alunas permanecem na escola de segunda a quinta-feira e na sexta-feira participam do Seminário de Estágio, onde ocorre um encontro coletivo com a equipe de estágio e/ou com o(a) orientador(a). Nessas ocasiões são propostas atividades como o estudo de temas que sejam de interesse do grupo, discussões de temáticas que abarquem situações vivenciadas durante o estágio, compartilhamento de experiências entre as estagiárias, entre outras propostas que são necessárias para qualificar o estágio de docência. Num segundo momento, são realizadas as orientações individuais e o acompanhamento dos planejamentos e registros realizados pelas alunas - este acompanhamento é feito também on-line (via e-mail ou outras estratégias).

Cabe salientar a importância do estágio no processo formativo das professoras e dos professores ${ }^{4}$ de educação infantil, já que durante o curso são restritas as oportunidades de aprofundar conhecimentos e vivenciar práticas específicas de docência na Educação Infantil. Assim, muitas vezes o fazer/pensar/refletir se dá no dia a dia quando as alunas estão imersas na prática com as crianças.

Acreditamos que é na experiência do estágio que ocorre a articulação das professoras com os fazeres da docência, isto é, as aprendizagens sobre as especificidades de ser professora de educação

\footnotetext{
${ }^{3}$ A área da Educação Infantil da UFRGS no ano de 2019 estava composta por 8 professores doutores, sendo seis mulheres e dois homens. Por esse motivo - e por ter sido uma das professoras do grupo que orientou o estágio que é foco deste artigo -, optamos por utilizar a escrita no feminino neste artigo.

${ }^{4}$ Nos últimos anos há um crescimento considerável de homens buscando o Curso de Pedagogia, mas ainda a grande maioria é formada por mulheres que constituem a função de professoras. Assim, no decorrer do artigo, optamos por utilizar a forma no feminino quando tratarmos de alunas, professoras, estagiárias e orientadoras.
} 
infantil, que se constituem a partir das relações com as crianças e suas famílias, na escuta atenta, no olhar minucioso, no planejamento das propostas e na busca por subsídios que fundamentem a prática. Enfim, a experiência no estágio vai se constituindo de uma grande "bricolagem"'s, isto é, uma montagem de diferentes repertórios que vai constituindo a docência com os bebês e as crianças pequenas.

Neste artigo, iremos apresentar dados e reflexões sobre uma experiência de estágio numa escola de educação infantil conveniada que foi foco de um estudo aprofundado 6 sobre o conceito de “desemparedamento” (TIRIBA, 2005), impactando de forma propositiva o cotidiano da escola.

$\mathrm{Na}$ primeira seção, iremos abordar $\circ$ referencial teórico sobre $\circ$ conceito de desemparedamento. Em seguida, iremos problematizar aspectos relacionados à experiência com o processo de desemparedamento durante o estágio curricular, bem como as reflexões produzidas na relação escola/universidade, professora/estagiária, crianças/famílias, destacando as potencialidades e as dificuldades deste processo.

\section{“Vamos no pátio!": os primeiros movimentos em direção ao desemparedamento.}

Tratamos aqui da proposta vivenciada durante o estágio curricular do Curso de Pedagogia em uma creche conveniada na área central do município de Porto Alegre, com um grupo de II crianças na turma de berçário, na faixa etária entre I e 2 anos. A equipe de profissionais que atuava com este grupo era composta pela estagiária, a professora titular e uma auxiliar pedagógica. O público atendido pela escola é de crianças em situação de risco social, ou seja, crianças em condições precárias de moradia, e/ou saneamento e/ou ausência de um ambiente familiar seguro, devido a problemas com drogas, entre outros. Neste contexto, o estágio foi desenvolvido articulando propostas e projetos de acordo com os interesses e as necessidades das crianças, os quais foram surgindo no decorrer da prática, e emergiram a partir de um olhar atento e de uma escuta sensível em relação às crianças; isto é, por meio das observações foram percebidas as demandas daquele grupo.

Uma das demandas mais pulsantes surgiu ao reconhecer que os espaços externos da escola não eram muito explorados e que, como consequência, as crianças também não tinham muito contato com elementos naturais, tais como areia, terra, água, folhas, plantas, sementes entre outros. Apesar disso, a escola dispunha de dois espaços externos: o pátio da frente, que era pequeno e cimentado,

\footnotetext{
${ }^{5}$ Bricolagem no sentido de que a construção da proposta está implicada numa experiência com vários elementos, tendo como base um processo de criação, de construção autoral da estagiária em formação.

6 Trabalho de Conclusão de Curso intitulado "O Processo de Desemparedamento Vivenciado na Prática Pedagógica do Estágio Curricular” (TUBINO, 2019), sob orientação da Professora Doutora Simone Albuquerque.
}

Olhar de professor, Ponta Grossa, v. 24, p. I-19, e-15955.006, 2021.

Disponível em <https://revistas2.uepg.br/index.php/olhardeprofessor> 
com alguns brinquedos plásticos; e o pátio dos fundos, que era um pouco maior, mas estava interditado, pois ficava em direção a uma comunidade considerada perigosa devido ao tráfico. Logo, as crianças tinham acesso limitado a estes espaços externos, e as propostas na longa rotina diária eram desenvolvidas dentro da sala de referência do grupo. É justamente essa vivência das crianças que contribui para reflexões como a de Léa Tiriba, que utiliza a expressão "emparedar" para designar a ação de "manter as crianças entre paredes" (2018, p. 17).

Partindo dessas observações, o estágio assumiu uma postura propositiva, buscando religar as crianças com a natureza, trazendo as crianças para fora da sala de aula. No processo de compreender sobre as vivências e as necessidades dos pequenos, encontramos um conceito potente que contribuiu no (re)conhecimento dos processos que estávamos vivenciando naquela escola. Por meio do conceito de "Desemparedamento" apresentado por Tiriba (2005), em sua tese de doutorado em educação, observamos a necessidade de as crianças retomarem este contato com o meio natural, isto é, o conceito auxiliou em nossa compreensão a respeito da necessidade das crianças em se religar com o que é, na realidade, um direito delas.

Partindo do "emparedamento", o conceito de "Desemparedar" é justificado pela autora a partir da promulgação da Constituição Brasileira (1988), na qual a educação infantil passa a ser um direito das crianças. Assim, afirma:

Considerando que chegam ainda bebês de poucos meses e permanecem matriculadas até os 5 ou 6 anos, pode-se dizer que, até essa época, a vida delas é nesse lugar. Vale perguntar, então: as rotinas possibilitaram um contato mais estreito com o mundo natural? O que há aí: terra, árvores, areia, o quê? Como as escolas se relacionam com o que existe na natureza para além dos humanos? (TIRIBA, 20I0, p. 69).

Nesta perspectiva, cabe à escola de educação infantil reconhecer que ela própria se constitui como o lugar e o tempo em que as crianças vivem sua infância, já que, na sociedade atual, a maioria das famílias necessita compartilhar o cuidado e a educação dos pequenos com esse espaço.

A autora relaciona o movimento de emparedamento nas instituições de educação infantil com três fatores. $O$ primeiro é a função do emparedamento como uma estratégia capitalista na qual o distanciamento da natureza gera um controle destes corpos, gerando a "produção de corpos dóceis de que o capitalismo necessita" (Tiriba, 2005, p. 13). Nesse sentido, a autora mostra que esse movimento de deslocamento do mundo natural inibe também o desejo e os interesses das crianças. "Assim, domínio da natureza e controle do corpo estão associados. Ou, em outras palavras, distanciamento da natureza e desatenção aos desejos do corpo são movimentos análogos" (Tiriba, 2005, p. 12).

O segundo fator responsável por este distanciamento, indicado pela autora, é o fato de haver uma relação "dos elementos do mundo natural com a sujeira, a desorganização, a doença, o perigo. 
Isto é, com aquilo que ameaça as organizações do cotidiano e da vida...” (Tiriba, 2005, p. 9). Existe ainda o terceiro fator apontado por Tiriba, que influencia este distanciamento crianças/natureza: é a supervalorização das aprendizagens em sala de aula, quando o conhecimento "passado/ensinado" é visto como mais importante do que as construções que as crianças fazem a partir das experiências e vivências nas quais a professora pode até vir a fazer intervenções, mas não será o centro.

Tiriba (2005, p. 10) mostra que o meio natural, por consequência desta concepção das aprendizagens e conhecimentos, acaba sendo visto apenas como um instrumento pedagógico, para atingir conhecimentos específicos. "Tanto os passeios, como a relação com a água, a vegetação, os animais acabam servindo para ensinar algo, numa perspectiva onde se valoriza em primeira mão o conhecimento abstrato, e a vivência concreta como meio de chegar ao abstrato".

Tiriba (2005, p. 10) aponta que ambos os tipos de conhecimentos são importantes e que as crianças devem ter contato com os dois. Contudo, mostra que:

(...) $\circ$ que se aprende com a natureza, em contato direto com o mundo, não se resume ao que se pode organizar racionalmente, de modo anteriormente planejado. Trata-se, então, de considerar as intervenções criativas das crianças, seus interesses presentes, pois é possível definir o que se ensina, mas jamais o que se aprende. Assim as vivências ao ar livre, os passeios no entorno podem ser entendidos como possibilitadores de aprendizagens de corpo inteiro, em que são incluídas a atenção curiosa, a contemplação, as sensações, as emoções, as alegrias! São aprendizagens que se realizam aqui e agora, não servem apenas para confirmar o que foi trabalhado de forma sistemática, antes ou depois.

As aprendizagens são, então, únicas para cada criança. Logo, as creches devem oferecer uma pluralidade de vivências e experiências para que as crianças tenham contato com todos os tipos de conhecimentos, possibilitando que se conheçam e se desenvolvam plenamente.

Tiriba (2010) também aponta que este contato com o ar livre, com a natureza e seus elementos, não pode ser visto como uma opção/escolha de cada professor ou professora, mas sim como um direito das crianças a ser respeitado. Assim, ter contato com a natureza e vivenciar as experièncias que só os elementos da natureza podem oferecer é um direito da criança e, principalmente, um dever da escola.

\section{Desemparedamentos e seus processos no contexto da escola}

Durante o estágio curricular, as expectativas e demandas das crianças eram repensadas diariamente, vivenciando o desafio de planejar propostas interessantes de exploração em espaços externos dependendo das condições climáticas. Desse modo, foi pensando nessas demandas que o processo de desemparedamento teve início.

Olhar de professor, Ponta Grossa, v. 24, p. I-19, e-15955.006, 2021.

Disponível em <https://revistas2.uepg.br/index.php/olhardeprofessor> 
A primeira vivência voltada para a natureza ocorreu ao final de uma tarde, situação em que as crianças estavam agitadas e os pais já estavam quase chegando. Havia começado a chover, então as crianças foram convidadas a ir até a janela para escutar o som da chuva. Nas duas cadeiras embaixo da janela, em duplas subiam para sentir o cheiro, ver e escutar o som da chuva.

A partir desse primeiro contato se iniciou um projeto intitulado "O brincar é natural: Descobrindo com a Natureza!", buscando promover o contato das crianças com a natureza. A intenção foi explorar diferentes elementos (terra, areia, barro, folhas, sementes, chuva, entre outros), experimentando diversas situações novas e prazerosas com esse contato, desde explorações livres destes elementos até desenhos com diferentes materiais naturais (barro, carvão, pedras, entre outros), pinturas utilizando diferentes elementos como suporte (galhos, folhas e sementes) e construção de um painel com os elementos utilizados na confecção de móbiles e mandalas.

Esse contato com diferentes materiais nos espaços externos tem grande importância, pois "em se tratando de crianças, o contato com a vegetação tem ainda mais impacto, de modo que a interação com a natureza influencia o desenvolvimento e também auxilia no aprendizado (...)” (MEC, 2014, p. 8).

Iniciando por convites e surpresas preparadas no pátio, as crianças e a escola foram sendo desafiadas a experimentar, sentindo e tocando materiais diversificados. A intenção do projeto foi oportunizar prazer e alegria para os momentos de livre exploração, permitindo que eles vivenciassem estes momentos de corpo inteiro e que tivessem autonomia nas suas criações. Esses momentos deixavam marcas nos espaços (no chão, nas paredes) e nos seus corpos. É interessante mencionar que esses convites foram vistos inicialmente com estranheza e resistência pelos adultos da escola.

Assim, com o andamento do projeto "O brincar é natural”, foi necessário convidar as professoras da escola, principalmente, a uma problematização: qual é a postura mais adequada diante das marcas deixadas durante as experimentações mais intensas das crianças, visando o seu desenvolvimento de forma integral? Este convite à reflexão e experimentação das professoras, apesar de não ter sido o objetivo do projeto, foi feito de forma a provocar que elas experimentassem as propostas junto das crianças.

A partir daí, o processo de desemparedamento foi se ampliando durante o estágio, e por meio dele a comunidade escolar também foi convidada a pensar sobre as propostas, os espaços e os materiais disponibilizados no ambiente da escola que poderiam ampliar as relações e as aprendizagens das crianças.

Horn (20I4, p. 9) apresenta a ideia segundo a qual "a organização dos espaços externos apoiase no projeto pedagógico da unidade, que deve nortear as ações das crianças e dos professores, 
oferecendo pistas importantes sobre a ideia de infância que desejam assegurar os educadores que ali atuam". Consideramos que pensar nos espaços e materiais se consolidou como um desafio para a escola a partir das experiências geradas no estágio. Durante este período, foi percebido dois grandes obstáculos nesse processo: a concepção de "sujeira" trazida pela escola, nas vivências mais intensas, e a ideia a respeito de como as crianças deveriam explorar, tendo como referência o fato de que elas não deveriam "estragar" os materiais nas propostas desenvolvidas - o que demonstra que a preocupação não focava na experiência com os materiais, mas sim com o produto final que deveria ser exposto, apresentado aos adultos da escola (familiares, coordenação e direção).

Embora as Diretrizes Curriculares Nacionais da Educação Infantil (DCNEl, 2009), em seu Art. $4^{\circ}$, afirme que o foco do currículo são as crianças, suas interações e a brincadeira, ainda encontramos no dia a dia das escolas uma grande preocupação com o produto final das experimentações e com as expectativas dos adultos. Nesta perspectiva, há um longo caminho a percorrer no sentido de centrar o currículo nos direitos das crianças, proposta já apresentada na DCNEI (2009) e consolidada nos seis direitos de aprendizagem e desenvolvimento dos bebês e crianças pequenas na Base Nacional Comum Curricular (2017), que são: conviver, brincar, participar, explorar, expressar e conhecer-se.

\section{“Olha a Janaina, tá mexendo nas tintas. Vai fazer bagunça ali...": a experiência das crianças a partir da concepção adultocêntrica}

Uma das experiências propostas no início do projeto foi um caminho sensorial com elementos da natureza, no qual esses elementos foram organizados em caixas vazadas, sobre um tecido, para que as crianças tivessem este primeiro contato. Por conta dos furos nas caixas, as professoras pediram que a areia fosse deixada dentro da sacola, para que não "sujasse" o pátio da escola, expressando a ideia de que a areia seria uma sujeira.

A ideia inicial da proposta era de que, no primeiro momento, as crianças pudessem explorar aqueles elementos apenas com os pés, fazendo o caminho com auxílio, e, em um segundo momento, elas pudessem explorar livremente. Como surgiu esta resistência, a proposta precisou ser alterada. Ficou claro que outras estratégias teriam de ser desenvolvidas, para lidar também com a concepção das professoras da escola.

Tiriba (2005, p. 9) indica esta definição de "sujeira" como um dos principais fatores responsáveis pelo afastamento das crianças com relação ao mundo natural.

O distanciamento se deve à identificação dos elementos do mundo natural com a sujeira, a desorganização, a doença, o perigo. Isto é, com aquilo que ameaçava as

Olhar de professor, Ponta Grossa, v. 24, p. I-19, e-15955.006, 2021.

Disponível em <https://revistas2.uepg.br/index.php/olhardeprofessor> 
organizações do cotidiano e da vida, planificadas e pautadas nos ideais de previsibilidade.

Tiriba (2005, p. 10) mostra que o contato com a natureza potencializa as aprendizagens: "as vivências ao ar livre, os passeios no entorno podem ser entendidos como possibilitadores de aprendizagens de corpo inteiro, em que são incluídas a atenção curiosa, a contemplação, as sensações, as emoções, as alegrias!". Mas problematiza o fato de não ser permitido às crianças ter este contato por inteiro:

Raramente de pés descalços, as crianças brincam sobre chão predominantemente coberto por cimento e brita, revestimentos que predominam nas áreas externas. Poucos pátios são de terra ou barro. A grama, onde existe, muitas vezes não está liberada para as crianças, sob o pretexto de que nela não se pode pisar. Por outro lado, onde ocupa a totalidade da área externa, não oferece alternativas de brincadeiras de cavar, amontoar, criar e demolir, atividades tão desejadas, que só a terra e a areia propiciam (TIRIBA, 2005, p. 8).

Esta resistência era claramente uma postura adultocêntrica, de enxergar as marcas como sujeira, não apenas no espaço, mas também no corpo das crianças. A presença de comentários tais como "Eles vão fazer bagunça", em momentos nos quais as crianças estavam numa experiência rica e prazerosa, como a experimentação das receitas de tinta ou dos desenhos em diferentes materialidades - como barro, argila, etc. -, demonstrava por parte das educadoras "desconforto" por não terem clareza das possíveis consequências daquelas vivências. É possível afirmar que nesta escola de educação infantil emerge a necessidade de um deslocamento de uma visão pedagógica centrada nos adultos para a perspectiva de ouvir, olhar e aprender com as crianças.

Sarmento (20II, p. 27) argumenta que, para lidar com essa visão centrada no adulto, é preciso que se esteja disposto a entender os desejos e necessidades do desenvolvimento das crianças. Dessa forma, apresenta que, para sair dessa postura adultocêntrica, é preciso "ouvir a voz das crianças".

Destacamos outra vivência com tinta que também foi marcada pela resistência dos adultos. A ideia inicial era que as crianças explorassem a tinta e pintassem com esponjas os móveis confeccionados com caixas, para a casinha da sala de aula que estavam montando. Contudo, antes que iniciasse a proposta, as professoras titulares e auxiliar sugeriram que este momento fosse feito em duplas, justificando a falta de experiência com tinta por parte das crianças.

Foi possível observar que as professoras ficaram ansiosas com esse momento, aconselhando que as tintas não fossem deixadas à disposição das crianças, mas que fossem sendo colocadas nas esponjas, demonstrando receio de que as crianças se sujassem ou fizessem bagunça no pátio. Durante a vivência, as professoras seguiram dando "conselhos" para ir controlando a quantidade e o manuseio nas pinturas das crianças. Esta ideia de sujeira está articulada com a relação construída na escola com as funcionárias que atuam na limpeza. Tiriba (2005, p. 9) descreve que as responsáveis pela limpeza 
contribuem para que as crianças e os espaços não sejam marcados, dentro das instituições, "elas limitaram as brincadeiras com água, com terra, com areia, elementos sempre identificados como 'sujeira”.' Cunha (2009, p. 10) observa que as instituições de educação infantil,

(...) deveriam ser o espaço inicial e deflagrador para o desenvolvimento das diferentes linguagens expressivas, tendo em vista que as crianças pequenas iniciam $\circ$ conhecimento sobre o mundo através dos cinco sentidos (visão, tato, olfato, audição, gustação), do movimento, da curiosidade em relação ao que está a sua volta, da repetição, da imitação, da brincadeira e do jogo simbólico. No que diz respeito às linguagens expressivas, estes são os fatores fundamentais para que elas se desenvolvam plenamente.

O perceber e o registrar as impressões sobre o mundo se dá num processo contínuo - processo expressivo - que vai se modificando na medida em que as crianças têm contato com as linguagens, com os materiais expressivos e com as intervenções dos adultos e de outras crianças. É na interação da criança com os objetos de conhecimento (desenho, pintura, modelagem, etc.) que o processo expressivo se constitui.

A partir desta concepção de que as crianças apreendem o mundo, expressam-se e registram suas aprendizagens com os cinco sentidos e em contato com as diferentes linguagens, estratégias foram sendo desenvolvidas ao longo do estágio para lidar com a resistência dos adultos às marcas expressas. Neste sentido, a análise da relação entre as marcas deixadas nas experimentações das crianças precisa ser discutida com todos os profissionais da escola, pois precisam ser considerados os aspectos educativos nas propostas desenvolvidas, bem como na organização dos direitos e deveres dos adultos e crianças dentro do contexto escolar.

\section{“Eles vão estragar...": explorar é diferente de estragar}

No decorrer do estágio curricular, por meio das propostas vivenciadas, fomos imprimindo no cotidiano da escola nossas concepções de educação infantil, de criança e de currículo. Horn (2014) relata que a prática das professoras oferece pistas sobre a ideia que elas trazem de infância. Esta questão foi observada numa das propostas vivenciadas, na qual foi apresentado para as crianças um "caminho sensorial”, montado com diferentes materiais recicláveis (papel camurça, lixas, caixas de ovo, rolhas cortadas, tampas de garrafa, saco bolha, plumagem branca e plásticos lisos ou frios).

Essa atividade teve a intenção de que, em um primeiro momento, em duplas, as crianças fossem explorando as diferentes texturas e sensações com os pés, e, em um segundo momento, fosse permitida a livre exploração desses materiais, para que pudessem buscar outras estratégias e vivenciar esta experiência de corpo inteiro e coletivamente. 
$\mathrm{Na}$ primeira parte da vivência, as professoras adoraram. Contudo, assim que o segundo momento iniciou e as crianças puderam explorar individual ou coletivamente novos enredos, novas aprendizagens, novas possibilidades de interagir com os materiais, as professoras ficaram muito surpresas e a todo momento comentavam que as crianças iriam "estragar" o tapete. Ficou muito evidente que a preocupação das professoras foi unicamente com a integridade do material e não com as possibilidades de exploração das crianças. A necessidade de um deslocamento do olhar da professora em relação ao foco do planejamento da proposta, percebendo que este deve ser as interações e aprendizagens das crianças, é um movimento importante que se articula no processo de “desemparedamento", o qual exige uma ação da professora na construção de propostas concretas. Cunha (2009, p. 21), explica que:

Geralmente a exploração dos materiais resulta na destruição dos trabalhos, pois para as crianças pequenas $\circ$ rasgar, o amassar, o furar, $\circ$ molhar fazem parte deste processo de descoberta. Os educadores não devem ficar preocupados com o aspecto da destruição, de não existir no final do processo um desenho ou uma pintura para ser colocada na pasta e ser mostrada aos pais. Ao contrário, os educadores devem incentivar as possibilidades de ações sobre os materiais, pois, neste momento o processo de conhecimento matérico é fundamental para as crianças e não um produto final.

Em diferentes momentos do estágio, foi possível observar este mesmo movimento de preocupação com a preservação dos materiais na sala, como, por exemplo, na organização do canto da leitura, que tinha como objetivo principal ser um espaço interativo, com alguns personagens na altura das crianças, para que pudessem ver e brincar neste espaço. Com relação a esse espaço, observamos que muitas vezes estes materiais estavam sobre a tenda que circunscrevia aquele espaço de leitura, ou, então, estavam guardados nas prateleiras para que as crianças não estragassem - mesmo que, ao final da tarde, todos os profissionais da sala dedicavam um tempo para repor e reorganizar os materiais, pois com a interação das crianças, alguns caiam ou eram arrancados.

Desse modo, foi necessária a construção de estratégias e propostas para além da relação com as crianças, também buscando envolver as professoras e a própria instituição nesse processo, sabendo da responsabilidade que a escola deve desempenhar neste contato entre as crianças e a natureza.

\section{“Olha que lindos! Registra esse momento!”: o movimento em busca da superação dos obstáculos}

Após perceber as resistências, iniciou-se um processo de diálogo com as professoras e com a instituição, buscando argumentar sobre as intencionalidades de cada experiência, antes, durante e depois da execução. O diálogo foi estabelecido com as professoras, bem como entre a orientadora do estágio e a coordenação da escola, possibilitando que a proposta desenvolvida fosse compreendida em 
toda a sua complexidade e, principalmente, apresentando os argumentos teóricos e metodológicos para as propostas desenvolvidas, buscando, desse modo, construir uma parceria, envolvendo as professoras e a gestão da escola nas vivências.

Ceppi e Zini (2013, p. 28) definem a escola como "um ambiente coletivo, baseado na participação e na gestão social, no trabalho coletivo, na sociabilidade e nos objetivos e valores compartilhados".

O estágio em docência na educação infantil é uma aposta nesta construção de parceria entre estagiária e professoras, escola e universidade. Nesta perspectiva, as professoras da sala sempre tinham acesso ao planejamento com antecedência, para trocar ideias, tomar ciência do que ocorreria e também opinar sobre as propostas.

Contudo, nem sempre foi possível estabelecer este diálogo no planejamento, pois em algumas semanas foi perceptivel que elas não o estavam lendo. Sendo assim, o primeiro movimento em busca da diminuição das resistências observadas foi começar a estabelecer este diálogo com as professoras da turma antes do envio do planejamento, buscando incluí-las e ir apresentando as intencionalidades, além de ir explicando de onde vinham as demandas das crianças e qual era a justificativa das propostas.

Esse movimento inicial ajudou muito no diálogo dentro de sala e na construção desta parceria com as professoras. Em muitas vivências, também foi possível estabelecer um diálogo com a responsável pela limpeza, que era uma das profissionais mais envolvidas neste movimento de desemparedamento. Uma estratégia interessante para consolidar a parceria com a funcionária da limpeza foi a de realizar a manutenção dos ambientes após as experiências, bem como a organização prévia e posterior às propostas.

Os reflexos dessas parcerias começaram a aparecer com o decorrer do estágio, quando se pôde perceber que as propostas passaram a ser mais aceitas e a terem uma maior participação das professoras, mesmo que inicialmente fosse apenas conversando com as crianças e não interferindo na proposta.

Destaco para esta análise a vivência de desenho com carvão que ocorreu no pátio, com várias telas (papel pardo e folhas coloridas) espalhadas: penduradas, no chão, nos tatames e em outros espaços. Nessa prática, as crianças buscaram formas de vivenciar os corpos para desenhar e explorar este novo elemento, experimentando a textura, a cor, a marca que o carvão deixava. Enfim, o material carvão, reconhecido pelas crianças como material para fazer fogo, era redimensionado numa proposta.

Inicialmente alguns estavam com receio de pegar o carvão e até limparam as mãos nas roupas quando perceberam que estavam sujas, mas depois foram ficando mais à vontade com a textura do material e foram explorando sem receio. 
As professoras, apesar de ainda receosas com as marcas deixadas pelo carvão, mostraram-se muito receptivas com relação à proposta. Nesta ocasião, elas ajudaram incentivando as crianças a desenhar e elogiando as que estavam realizando a tarefa. Uma das professoras que estava observando a proposta chamou a atenção para uma interação que estava ocorrendo - uma das crianças descolou a folha que estava colada na parede e colou na casinha, convidando outro amigo para desenhar - e sinalizou "Olha que lindos... Registra esse momento". Neste episódio, ficou claro que as professoras estavam começando a ter esse olhar mais sensível para as experiências e explorações das crianças e das interações entre elas.

Essa superação se intensificou de fato na proposta de desenho no barro, na qual o ambiente do pátio foi preparado com lonas dispostas no chão e uma sobre a mesa, na qual foi colocada uma camada de barro, ao alcance das crianças, com o objetivo de que elas experimentassem aquela materialidade. Para esta proposta, camisetas foram colocadas nas crianças para que não se preocupassem com as roupas.

Esta experiência teve a participação da coordenadora da escola, que ajudou a organizar o espaço, e também a participação da orientadora de estágio. $O$ envolvimento delas motivou as professoras da sala a se envolverem ainda mais na execução da proposta, de modo que foram se desafiando, comentando "se tu encostar eu encosto...", até que elas passaram a encostar no barro, desenhar e incentivar as crianças a explorar.

A ideia de propor esta experiência com barro de areia veio justamente com o objetivo de iniciar as explorações com este elemento, já que na escola as crianças não tinham contato com a terra. Inicialmente, as crianças ficaram com receio de tocar e mexer no barro, apesar de todas terem ficado reunidas ao redor da mesa, com bastante curiosidade e interesse, já que o barro, produzido com areia e água, tinha uma textura, um cheiro, uma temperatura, uma densidade, que gerava um convite à experimentação para alguns e para outros apenas a observação. Após, foram entregues alguns gravetos para que superassem esse receio e fossem ousando na interação com o barro.

Durante a exploração, a coordenadora da escola chamou algumas professoras de outras salas para olhar a proposta. Esse incentivo fez com que as professoras da sala, que já estavam nesses processos, repensassem estas participações. É importante destacar que este envolvimento mais intenso por parte das professoras foi motivado pela presença da coordenadora da escola e da orientadora da universidade, mas se manteve nas propostas seguintes.

Ao final desta experiência, tivemos o momento de limpeza com as crianças, que foi outro marco importante no estágio. Um balde de água foi utilizado para lavar as mãos das crianças, esse momento ocorreu de maneira divertida. 
Os momentos de contato com o elemento água, para exploração, eram muito raros, geralmente ocorriam apenas como momentos de higiene, após brincadeiras com tinta, na pia do banheiro da sala. Mas após esta experiência com barro, durante a limpeza, a pedagoga da escola expressou que, nos dias quentes, experiências com água seriam bem-vindas, utilizando as piscinas e a mangueira da escola.

Contudo, o receio das professoras surgiu novamente em relação ao que a água poderia acarretar nas crianças e nas reações dos pais ao saberem deste contato. "O medo da doença, a reação dos pais, a dinâmica de funcionamento institucional, especialmente as rotinas e limpeza: tudo parece concorrer para que o contato com a água seja rarefeito" (TIRIBA, 2018, p. 79). A pedagoga iniciou, então, um movimento com todas as turmas, avisando as famílias que nos dias mais quentes teríamos este contato com a água. Este diálogo da escola com as famílias deixou as professoras mais tranquilas e abertas para receber e também propor experiências.

As famílias já se apresentavam muito tranquilas em relação às marcas desde o início do estágio. Mas, após esta conversa da escola com as famílias, foi possível perceber uma acolhida maior das famílias em relação à exploração de elementos como areia, terra, conchas, pedras, folhas, água, argila, farinhas, erva mate, amido, borra de café, chás, galhos, folhas, flores, cascas, pinhas, sementes, entre outros. Muitas começaram a enviar roupas de banho (biquínis e sungas) e a questionarem, no momento da saída, se as crianças tinham brincado com água e como tinha sido.

Como a escola já tinha dado o aval para o contato com a água, após as explorações mais intensas, que deixavam marcas, começamos a trazer as piscinas e permitir que as crianças se limpassem enquanto brincavam com este elemento. Para além dos momentos de higiene, durante a escovação dos dentes e a lavagem das mãos antes das refeições, a água começou a ser apresentada na escola como um elemento cheio de novas e ricas possibilidades. Tiriba (2018, p. 77) problematiza o acesso a este elemento, falando, a partir de entrevistas realizadas em algumas escolas, que mesmo nas unidades em que este elemento é explorado, "em geral, as respostas apontam para uma relação funcional, utilitária com esse elemento da natureza: serve para limpar os espaços e para fazer a higiene das crianças".

O contato com a água começou a ser incluído nos planejamentos, mas, como dependia do clima, na grande maioria das vezes, esse contato era encaixado ao final de alguma proposta que tivesse deixado marcas - em especial com tinta e desenho no barro. As vivências com sabão foram pensadas dentro do planejamento de maneira que, se o clima não estivesse bom, pudessem ser remanejadas dentro da semana. 
Geralmente, as vivências com água eram apresentadas como uma surpresa e isso tornava o momento muito mais atrativo e envolvente. As professoras participavam muito nestes momentos, enchendo a piscina e também fazendo registros.

Fica claro, então, que a escola é baseada na construção de relacionamentos e que estes precisam ser compartilhados e promovidos pela gestão da escola. Na experiência com água foi possível reconhecer a importância desta relação entre professores, gestores e famílias para que se possa realizar um trabalho pensando no desenvolvimento integral das crianças.

\section{“Faz bem pra pele, né, prof.”: superação dos obstáculos}

Com a superação dos obstáculos, foi possível vivenciar um estágio em que as propostas passaram a ter maior liberdade de experimentação, sendo vivenciadas de corpo inteiro por todos os envolvidos. Com isso, as crianças, em especial, tiveram mais abertura para explorar e se expressar de diferentes formas, respeitando os diferentes tempos.

Cunha (2009, p. 10) mostra que "Para que as crianças tenham possibilidades de desenvolveremse na área expressiva, é imprescindível que o adulto rompa seus próprios estereótipos, a fim de trazer à tona o universo expressivo infantil". A autora trata também da liberdade das crianças ao se expressarem, destacando que nessas ocasiões todas as coisas viram "um grande campo de possibilidades para os rabiscos e as manchas. Paredes, livros, mesas, cadeiras e o próprio corpo são marcados nas experiências do exercício sensório-motor" (CUNHA, 2009, p. 19).

Vale destacar que o corpo, que já era foco desde o início do estágio, pode ser mais explorado, acolhendo as suas potencialidades, tornando-se inclusive tela para as crianças se expressassem. Foi neste movimento que a escola se abriu para o projeto Brincar é natural e passou a fazer uma mobilização de arrecadação de areia e terra preta junto das famílias. Essa mobilização por parte da escola veio a partir das observações da coordenação da escola, nas experiências que estavam sendo desenvolvidas com as crianças. A partir deste momento, a escola começou a solicitar elementos da natureza para os pais nos momentos de chegada e saída, por meio de conversas - explicando que a escola estava sentindo falta desses elementos no ambiente escolar.

As famílias começaram, então, a levar potes e sacos com um pouco de areia ou terra preta e entregavam para as professoras. Esses elementos ficavam dispostos em cestos no saguão, junto ao ateliê da escola, e as professoras tinham liberdade para pegar e usar nas suas propostas com as crianças.

A falta de contato com a natureza no âmbito escolar ficou clara desde o início do estágio, pois a escola não possuía terra, espaços com grama, areia, ou canteiro; o único elemento natural presente 
era um pequeno limoeiro cercado por um pneu, que ficava no pátio da frente e que, por ter espinhos, as crianças não tinham muito contato.

Para Post e Hohmann (2003, p. 275), a questão sensorial que este contato natural oferece ajuda nas relações e na compreensão de mundo das crianças, “(...) Embora os bebês e as crianças pequenas não digam muito enquanto passam por estas experiências, estão a ganhar uma compreensão essencial sobre o mundo natural através das suas ações e da sua recepção sensorial”.

Aproveitando a receptividade da escola, o projeto Brincar é natural teve sequência. Articulado a questões de corporeidade, foram realizadas vivências buscando o contato das crianças com os espaços externos da escola, e as práticas foram acontecendo já sem tanta preocupação com as marcas, podendo ser explorado o espaço sem as roupas, deixando as crianças apenas com as fraldas, calcinhas e cuecas.

Cunha (2009, p. 2I) aborda a importância de os educadores buscarem promover e incentivar ações sobre diversos materiais, destacando que "o processo de conhecimento matérico é fundamental para as crianças...". Por "matérico", Cunha (2009) se refere a materiais expressivos como: tintas, argila, papéis, entre outros, tendo em vista que as crianças iniciam a descoberta do mundo partindo dos sentidos. Partindo dessa concepção, foram realizadas vivências apresentando esses diferentes elementos, explorando-os com utensílios de cozinha doados pelas famílias e panelinhas de brinquedo da sala. As professoras participaram intensamente das construções e dos enredos junto com as crianças, que foram sendo convidadas para novas formas de explorar os elementos e brincar coletivamente.

Durante o estágio, o brincar no espaço externo foi para as crianças um momento muito especial. Tiriba (2005, p. II) assinala que "As crianças têm verdadeiro fascínio pelos espaços externos porque eles são o lugar da liberdade". Contudo, não é suficiente dar este espaço e deixar as crianças soltas, é preciso tornar estes espaços potentes e atraentes. Este foi o grande desafio como docente: construir uma postura provocativa a partir das interações nos espaços.

Horn e Silva (2008, p. 16) abordam esse assunto, destacando que a postura do professor precisa estar de acordo:

(...) não basta "dar" às crianças o direito de brincar. Para ser uma atividade significativa, é preciso despertar e manter seu desejo pelo brincar. Não basta apenas ampliar o tempo no pátio ou aumentar os estoques de brinquedos na sala, pois isso implicará, principalmente, numa nova postura do professor diante da brincadeira e diante do espaço em que ela acontece.

Neste sentido, organizar os espaços e experimentar os materiais se articulava com a postura das professoras, que participavam. Sabendo que nesta idade as crianças precisam de espaço para realizar essas expressões, nos momentos de pintura foi buscado ampliar estes espaços, telas foram 
colocadas nas paredes, no chão e, também, penduradas no teto. Esta exposição sobre a exploração nesta fase tem por base Cunha (2009, p. 20) quando explica:

Neste momento de exploração espacial e matérica, as crianças necessitam de grandes superfícies de papel, não sendo adequado fornecermos folhas tamanho ofício. O papel pardo em metro e os grandes formatos de papelões das embalagens, além de muito resistentes às ações e à água, são mais convenientes, pois podemos forrar as mesas, as paredes e o chão com estes suportes. É interessante propormos atividades além das mesas, para que tanto a percepção visual como a gestualidade corporal e, em especial do braço/mão, sejam exploradas de outras maneiras.

As professoras passaram a ter outro olhar e a apontar para as diferentes explorações com encantamento pelas descobertas, o que tornou as propostas muito mais acolhedoras e envolventes. Conforme as crianças foram percebendo que as investidas delas não iam ser bloqueadas, foram adquirindo liberdade para suas investigações. A ideia de deixar as crianças explorarem e vivenciarem intensamente as experiências permitiu que sentissem prazer em estar naquele ambiente escolar. Segundo Horn e Silva (2008, p. I5):

Privar a criança de viver intensamente em favor de um treinamento mecânico é represar sua energia, é não aproveitar suas capacidades, é podar-lhe a curiosidade, sua abertura para explorar o meio em que vive; é substituir a aprendizagem significativa pelo condicionamento, enfim, impedi-la de ser criança, enquanto criança.

Os espaços externos são muito potentes, não por si só, mas a partir das oportunidades geradas para as crianças. Barros (2018, p. 63) fala que, para além do tamanho do espaço, é necessário a presença de elementos e materiais no espaço em questão para que tanto as crianças como os adultos queiram permanecer nele:

\footnotetext{
Uma tendência é acreditar que o tamanho é o principal fator para que o pátio seja esse espaço mas na verdade, as experiências vividas e também as pesquisas apontam que elementos como árvores, sombras, galhos soltos, sementes, flores, terra, água, cordas e a maneira como estão organizados exerce grande influência nas atividade e no desejo de permanência no pátio, tanto por parte dos alunos quanto do educadores.
}

A experiência com bolhas de sabão merece destaque, pois foi muito intensa e teve um grande envolvimento tanto por parte das crianças como das professoras. Este momento ocorreu no pátio, onde além de espalhar bacias com uma mistura para fazer as bolhas, também foi colocado uma piscina cheia desta mesma mistura, para que eles explorassem usando hastes para fazer as bolhas. Inicialmente o grupo foi reunido para sentar em volta do pote, onde os materiais foram apresentados e foi feita uma demonstração de como fazer as bolhas, o que gerou muita empolgação. Em seguida, as hastes foram entregues para cada um e eles começaram a explorar recebendo auxílio quando necessário. Conforme eles foram brincando e fazendo as bolhas, acabaram criando uma grande camada de espuma 
nas bacias, que foi explorada com muita curiosidade, oportunizando uma nova experiência, explorando a espuma em seus corpos e no espaço.

Por conta da intensidade da exploração, ocorreu a continuidade dessa experiência com a água: uma segunda piscina, apenas com água, foi disposta no pátio para ir tirando o sabão do corpo com ajuda de um balde. Nesta proposta, a água foi intensamente vivenciada a partir das interações e brincadeiras entre as crianças e também com os adultos.

O encerramento do projeto ocorreu juntamente com o encerramento do estágio, situação em que foi realizada uma visita em uma escola municipal de educação infantil vizinha, localizada numa praça em frente, com o objetivo de fazermos um piquenique. Como nesta escola o espaço era maior e havia a presença de diversos elementos naturais no pátio, foi um momento muito rico, no qual as crianças tiveram a oportunidade de brincar com água, areia, sementes, árvores, plantas, pedras... em um só tempo e espaço. $O$ encantamento dos pequenos foi permeado pelos convites dos novos amigos para que se aventurassem naquele espaço, permitindo novas brincadeiras e interações entre os pares que se formavam para a exploração do pátio. A intenção era que aquela visita na escola vizinha fosse apenas a primeira de muitas, já que a parceria já estava iniciada. Construir vínculos e parcerias entre escolas públicas e conveniadas é uma possibilidade de oportunizar novas experiências para as crianças naquele espaço qualificado e rico de materiais.

Acreditamos que esta visita foi um momento que envolveu toda a escola, a equipe da cozinha, a responsável pela limpeza, as estagiárias da fonoaudiologia, a coordenadora da escola e as professoras da sala. Todos os profissionais contribuíram para aquele evento, que era um grande desafio para todos que se envolveram neste convite, já que era a primeira saída do grupo. Assim, foi um momento de exploração, brincadeira, mas também de muito cuidado.

\section{Conclusão}

Tiriba (2005, p. 10) fala que "as vivências ao ar livre, os passeios no entorno podem ser entendidos como possibilitadores de aprendizagens de corpo inteiro, em que são incluídas a atenção curiosa, a contemplação, as sensações, as emoções, as alegrias!”. Acreditamos que é papel da escola oportunizar o contato com o meio natural, que é algo que as crianças buscam naturalmente. A pesquisadora destaca que “ (...) os seres humanos buscam o encontro porque têm sua origem neste mundo natural...” (TIRIBA, 20I8, p. I53). Especificamente sobre as crianças, a autora mostra que “(...) as crianças desejam tanto esse encontro porque são seres biofílicos, isto é, apegados ao mundo natural e a seus seres, que têm um senso de pertencimento, de filiação e de união à natureza". (TIRIBA, ibid.). Contudo, ela destaca que, apesar desse desejo pela natureza, é preciso que essa tendência seja alimentada para que se desenvolva. 
Se o movimento infantil é, claramente, o de conexão; se esse desejo expresso revela o impulso em busca da integridade do ser, as relações de proximidade com elementos naturais precisam ser compreendidas, pelas escolas e seus educadores, como um direito humano (TIRIBA, 2018, p. I54).

Com as análises destas experiências de desemparedamento durante o estágio, e com o aprofundamento teórico realizado ao longo deste artigo, foi possível constatar que este movimento de pensar para além da sala de aula nada mais é do que uma retomada por este contato que é natural. $E$ que, como professoras da educação infantil, temos o dever de proteger este direito das crianças ao contato com o mundo natural.

Neste sentido, é possível afirmar que o estágio é uma experiência formativa na constituição da docência para todos os envolvidos, já que emerge dos estudos e reflexões propostos no âmbito da universidade, chegando na escola a partir das propostas de estágio que são negociadas e dialogadas com professora e coordenação pedagógica. Este processo é dinâmico, constituindo-se num convite à reflexão das certezas com relação às práticas e num processo de experimentação. $O$ relato apresentado neste artigo destaca que, quando o convite é aceito, uma proposta potente pode ser partilhada entre crianças e adultos, pois estes acreditaram no diálogo, na troca, na invenção e na experimentação.

\section{Referências}

BARROS, M. I. A. de (Org.). Desemparedamento da infância: A escola como lugar de encontro com a natureza. 2. ed. Rio de Janeiro: Alana, 2018.

BRASIL. Ministério da Educação. Diretrizes Curriculares Nacionais para a Educação Infantil. Brasília: MEC,2009. Disponível em: <http://ndi.ufsc.br/files/2012/02/Diretrizes-Curriculares-para-a-EI.pdf\&amp;gt>. Acesso em: Fev. 2020.

BRASIL. Ministério da Educação. Base Nacional Comum Curricular. Brasília. 2017. Disponível em:<http://basenacionalcomum.mec.gov.br/images/BNCC_EI_EF_II05I8_versaofinal_site.pdf.> Acesso em: Fev. 2020.

BRASIL. Constituição (1988). Constituição da República Federativa do Brasil. Brasília, DF: Senado Federal: Centro Gráfico, 1988.

BRASIL. Ministério da Educação. PROJETO DE FORTALECIMENTO INSTITUCIONAL DAS SECRETARIAS MUNICIPAIS DE EDUCAÇÃO NA FORMULAÇÃO E IMPLEMENTAÇÃO DA POLÍTICA MUNICIPAL DE EDUCAÇÃO INFANTIL. Brasília. 2014

CEPPI, G.; ZINI, M. Crianças, espaços, relações: como projetar ambientes para a educação infantil. Porto Alegre: Penso, 20I3. 160 p. 
CUNHA, S. R. V. da (Org.). Cor, som e movimento: A expressão plástica, musical e dramática no cotidiano da criança. 7. ed. Porto Alegre: Mediação, 2009. 132 p.

HORN, C. I.; SILVA, J. S. da. O brincar na infância: Considerações a partir de uma pesquisa. Reflexão e ação, Santa Cruz do Sul, v. I, n. 16, jan. 2008. Quadrimestral. Disponível em: < http://dx.doi.org/I0.17058/rea.vl6il.33I >. Acesso em: Jan. 2020.

HORN, M. da G. S. Sabores, cores, sons, aromas: A organização dos espaços a Educação Infantil. Porto Alegre: Artmed, 20I4. 120 p.

SARMENTO, M. J. Conhecer a infância: os desenhos das crianças como produções simbólicas. In: FILHO, A. J. M.; PRADO, P. D. (Orgs.). Das pesquisas com crianças à complexidade da infância. Campinas: Autores Associados, 20II.

TIRIBA, L. Crianças da Natureza. Ministério da Educação e do desporto. Coordenadoria de Educação Infantil. Brasília: MEC/SEF, 20I0. Disponível em:

<http://portal.mec.gov.br/index.php?opition=com_docman\&amp;taskdoc_download\&amp;gid=6 679\&amp;Itemid=\&gt>. Acesso em: Jan. 2020.

TIRIBA, L. Crianças, natureza e educação infantil. 2005. Tese (Doutorado em Educação) Pontifícia Universidade Católica do Rio de Janeiro, Rio de Janeiro, 2005. Disponível em: <http://www2.dbd.puc-rio.br/pergamum/biblioteca/php/ >. Acesso em: Jan. 2020.

TIRIBA, L. Educação infantil como direito e alegria: Em busca de pedagogias ecológicas, populares e libertárias. São Paulo: Editora Paz e Terra Ltda, 2018.308 p.

TUBINO, B. da C. O processo de desemparedamento vivenciado na prática pedagógica do estágio curricular. 2019. Trabalho de conclusão de curso - Universidade Federal do Rio Grande do Sul, Porto Alegre, 2019. Disponível em: https://lume.ufrgs.br/handle/I0183//99290. Acesso em: Março de 2020.

Recebido em: 13 de junho de 2020.

Versão corrigida recebida em: 0I de julho de 2020.

Aceito em: II de setembro de 2020.

Publicado online em: 12 de março de 202 I

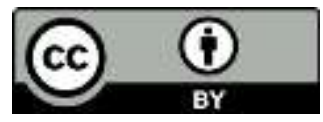

Olhar de professor, Ponta Grossa, v. 24, p. I-19, e-15955.006, 2021.

Disponível em <https://revistas2.uepg.br/index.php/olhardeprofessor> 